\title{
ANALISIS PENERAPAN PRINSIP-PRINSIP KOPERASI DALAM UNDANG-UNDANG KOPERASI (Studi Undang-Undang No. 25 Tahun 1992 dan Undang-Undang No.17 Tahun 2012)
}

\author{
Aji Basuki Rohmat \\ Pegawai Koperasi Simpan Pinjam Global Multiguna \\ ajibasukirohmad@gmail.com
}

\begin{abstract}
Studied law build cooperative efforts very closely related to the economic system adopted by a State, because the legal build cooperative efforts is to learn about the ideology, ideology and economic system adopted by the State. Implementation of the application of the Act cooperative must pay attention to the development of co-operative principles are applied internationally, in this case the cooperative principles set out the International Cooperative Alliance and other business practices. This study uses normative juridical approach, in which the specification of research using descriptive analysis that researchers seek will describe the application of the principle of cooperation in an Act. The results obtained show that Law No.25 of 1992 on Cooperatives have applied the principles of cooperative and is in conformity with Article 33 paragraph (1) and paragraph (4) of the Constitution of 1945. In order to repair and renewal of cooperative law, Cooperative Act 25 of 1992 in 2012 renewed by Act 17 of 2012. However, Act 17 of 2012, by most practitioners and cooperative actors considered incompatible with the cooperative identity, so is referred Judicial Review as to Law 17 of 2012 to the Constitutional Court. In its decision the Constitutional Court annul the Cooperative Act 17 of 2012, Since the Act 17 of 2012 is contrary to Article 33 paragraph (1) and (4) of the Act of 1945
\end{abstract}

Keywords : Application of the principles of cooperatives, Act.

\begin{abstract}
Abstrak
Mempelajari hukum bangun usaha koperasi sangat berkaitan erat dengan sistem perekonomian yang dianut oleh suatu Negara, karena hukum bangun usaha koperasi adalah mempelajari tentang faham, ideologi dan sistem perekonomian yang dianut oleh Negara. Implementasi penerapan Undang-Undang koperasi harus memperhatikan perkembangan prinsip-prinsip koperasi yang diterapkan secara Internasional, dalam hal ini prinsip-prinsip koperasi yang ditetapkan Internasional Cooperative Alliance dan praktek-praktek bisnis lainnya. Penelitian ini menggunakan metode pendekatan yuridis normatif, dimana spesifikasi penelitian menggunakan deskriptif analisis yaitu peneliti berusaha akan menggambarkan penerapan prinsip koperasi dalam suatu Undang-Undang. Hasil penelitian yang diperoleh menunjukkan bahwa Undang-Undang No.25 Tahun 1992 Tentang Perkoperasian sudah menerapkan prinsip-prinsip koperasi dan sudah sesuai dengan Pasal 33 ayat (1) dan ayat (4) Undang-Undang Dasar 1945. Dalam rangka perbaikan dan pembaharuan hukum koperasi, Undang-Undang Koperasi No.25 Tahun 1992 pada tahun 2012 diperbaharui dengan UndangUndang No.17 Tahun 2012. Namun Undang-Undang No.17 Tahun 2012, oleh sebagian praktisi dan pelaku koperasi dianggap tidak sesuai dengan jati diri koperasi, sehingga diajukanlah Judicial Riview atas Undang-Undang No.17 Tahun 2012 ke Mahkamah Konstitusi. Dalam keputusannya Mahkamah Konstitusi membatalkan Undang-Undang Koperasi No.17 Tahun 2012, Karena Undang-Undang No.17 Tahun 2012 bertentangan dengan Pasal 33 ayat (1) dan (4) Undang-Undang Dasar 1945.
\end{abstract}

Kata kunci: Penerapan, prinsip-prinsip koperasi, Undang-Undang 


\section{A. PENDAHULUAN}

Koperasi adalah "soko guru" sebagai bagian integral dan tak terpisahkan dari tata perekonomian nasional, maka koperasi bukan hanya amanah konstitusi namun sekaligus menjadi harapan dalam membangun ekonomi rakyat, bahkan bapak Koperasi Indonesia Moh. Hatta secara ekstrem menyatakan bahwa koperasi merupkan satu satunya wadah aparat produksi. Pasal 33 ayat (2) UndangUndang Dasar 1945 manyatakan bahwa bangun usaha di Indonesia selain Koperasi adalah Perusahaan Negara (BUMN/D) dan Perusahaan Milik Swasta (BUMS), namun semangat menjadikan koperasi sebagai soko guru perekonomian nasional merupakan cita cita yang harus diwujudkan.

Seiring dengan perubahan tata perekonomian global, berakibat pula terhadap paradigma dan tantangan perkoprasian di Indonesia. Pemerintah Indonesia menganggap bahwa Undang-Undang No.25 Tahun 1992 dipandang sudah tidak sesuai dengan kebutuhan hukum dan perkembangan perkoperasian. Setelah beberapa kali diadakan seminar dan perdebatan yang cukup panjang, Undang-Undang No. 25 Tahun 1992 yang sudah lebih dua puluh lima tahun berlaku diperbarui dengan UndangUndang No.17 Tahun 2012. Undang-Undang No.17 Tahun 2012 ini dibuat dengan maksud untuk menyesuaikan keadaan perekonomian global yang bergerak cepat dan semakin dinamis, agar koperasi dapat melakukan penyesuaian dan penetrasi ekonomi di pasar global, bukan merupakan sesuatu yang sulit dan tidak mungkin.

Pada sisi yang lain pengelolaan koperasi yang didasarkan pada prinsip koperasi mempunyai peran yang sangat setrategis dalam perekonomian Indonesia, diakui bahwa sampai dengan saat ini perkembangan koperasi tidak seperti di negara lain, seperti negara Jerman, Jepang dan negara lainya.

Pemerintah bersama dengan Dewan Perwakilan Rakyat dalam memperkuat dan memperkokoh sektor usaha koperasi dalam rangka mengsejajarkan dengan sektor usaha lainya, dan untuk menghadapi persaingan global, maka Undang-Undang No.25 Tahun 1992 perlu dilakukan perbaikan, dan karena itu lahirlah Undang-Undang No. 17 Tahun 2012 yang disahkan pada tanggal 30 Oktober 2012, sebagai penganti Undang-Undang No.25 Tahun 1992.

Sebagai payung hukum yang mengikuti kebutuhan hukum dan perkembangan perkoperasian, UndangUndang No. 17 Tahun 2012, sebagai mana yang disebut dalam penjelasanya, bahwa Undang-Undang No.17 Tahun 2012 memuat pembaharuan hukum, sehingga mampu mewujudkan koperasi sebagai organisasi ekonomi yang sehat, kuat, mandiri dan tangguh serta terpercaya sebagai entitas bisnis, yang mendasarkan kegiatanya pada nilai dan prinsip koperasi. Akan tetapi kelahiran Undang-Undang No.17 Tahun 2012 ini, justru menimbulkan perdebatan hukum di antara para pelaku gerakan koperasi, pakar perkoprasian, lembaga swadaya masyarakat yang bergerak dibidang perkoperasian dan para pakar hukum. Bahkan ada beberapa pegiat koperasi yang mengajukan gugatan kepada Mahkamah Konstitusi perihal Undang-Undang No.17 Tahun 2012 tersebut diantaranya, Gabungan Koperasi Pegawai Republik Indonesia (GKPRI) Propinsi Jawa Timur, Pusat Koperasi Unit Desa (PUSKUD) Jawa Timur, Pusat Koperasi Wanita (Puskowanjati) Jawa Timur, Pusat Koperasi An-Nisa Jawa Timur, Pusat Koperasi BUEKA Assakinah Jawa Timur.

Undang-Undang yang mengatur tentang koperasi yang pernah berlaku di Indonesia lebih dari 9 Undang-Undang, maka untuk membatasi agar tidak luas cakupan pembahasnya, penulis hanya menganalisis dua Undang-Undang yakni Undang-Undang No.25 Tahun 1992 dan Undang-Undang No. 17 Tahun 2012. Berdasarkan hal-hal yang penulis uraikan tersebut diatas, maka penulis mengemukkan permasalahan sebagai berikut:

1. Bagaimana penerapan prinsip koperasi dalam Undang-Undang No.25 Tahun 1992 dan Undang-Undang No.17 Tahun 2012? 
2. Mengapa Mahkamah Konsitusi membatalkan Undang-Undang Koperasi No.17 Tahun 2012?

\section{B. METODE PENELITIAN}

Penelitian ini menggunakan metode pendekatan Yuridis Normatif, yakni peneliti menggunakan bahan kepustakaan, yang mencakup tentang idiologi perekonomian yang dianut suatu negara sebagaimana tertuang dalam hukum dasarnya (UUD), pengertian koperasi, prinsip-prinsip koperasi dalam Undang-Undang No. 25 Tahun 1992 dan Undang-Undang No. 17 Tahun 2012, serta putusan Mahkamah Konstitusi yang berkaitan dengan masalah penelitian ini. Spesifikasi penelitian ini menggunakan penelitian deskriptif analitis, adalah penelitian yang berusaha mengambarkan penerapan prinsip-prinsip koperasi dalam UndangUndang No.25 Tahun 1992 dan UndangUndang No.17 Tahun 2012, serta alasan Mahkamah konstitusi membatalkan UndangUndang Koperasi No.17 Tahun 2012.

\section{HASIL PENELITIAN DAN PEMBAHASAN}

1. Penerapan Prinsip-Prinsip Koperasi Dalam Undang-Undang No.25 Tahun 1992 dan Undang-Undang No.17 Tahun 2012.

Secara etimologi, koperasi berasal dari bahasa Inggris, yaitu cooperatives, merupakan gabungan dua kata co dan operation yang artinya co bersama dan operatives bekerja.

Definisi koperasi menurut International Cooperative Alliance (ICA) dalam konggres ke 100 di Manchester tahun 1995 telah mengesahkan ICA Cooperative Identity Statement (ICIS) dan mendefinisikan koperasi sebagai ; "An autonomous association of person united voluntarily to meet their common economic, social ang cultur needs and aspirations through a jointly-owned and democratically controlled enterprise".

Prinsip Koperasi menurut International Cooperatives Alliance pada konggres tahun 1966 adalah;
Pertama, keanggotaan koperasi secara terbuka tanpa adanya pembatasan yang dibuat-buat; Kedua, kepemimpinan yang demokratis atas dasar satu orang satu suara; Ketiga, modal menerima bunga yang terbatas, itupun bila ada; Keempat, sisa hasil usaha dibagi tiga; sebagian untuk cadangan, sebagian untuk masyarakat dan sebagian untuk dibagikan kembali kepada anggota sesuai jasa masing-masing; dan prinsip ini ditambah dengan dua prinsip yang lain yaitu; Pertama, semua koperasi harus melaksanakan pendidikan secara terus menerus; dan Kedua, gerakan koperasi harus melaksanakan kerja sama yang erat, baik di tingkat regional, nasional maupun internasional.

Bapak koperasi Indonesia mengatakan bahwa koperasi adalah usaha bersama untuk memperbaiki nasib penghidupan ekonomi berdasarkan tolong menolong dan sebagai suatu organisasi yang setidak-tidaknya melaksanakan empat asas atau prinsip yaitu; Pertama tidak boleh dijual dan dikedaikan barangbarang palsu; kedua harga barang harus sesuai harga barang setempat; ketiga ukuran harus benar dan terjamin; keempat jual beli dengan tunai.

Berdasarkan prinsip-prinsip koperasi yang disebutkan diatas maka dapat penulis simpulkan dan sekaligus penulis analisis bahwa prinsip-prinsip koperasi setidak tidaknya terdiri atas;

1. Keanggotaannya bersifat sukarela dan terbuka;

prinsip ini mengandung arti bahwa seseorang untuk menjadi atau tidak menjadi anggota koperasi tidak boleh dipaksakan, jadi atas kesadaran sendiri. Globalisasi adalah keterbukaan dan kebebasan, prinsip koperasi ini sangat sesuai. Adanya sifat keterbukaan ini membuat koperasi tidak mengenal batas-batas dan diskriminasi apapun.

2. Prinsip pengelolaan dilakukan secara demokratis. 
Pengelolaan disini tidak terbatas pada manajemen saja namun meliputi pengawasannya. Setiap anggota mempunyai hak dan kewajiban yang sama didalam koperasi, hak mengusulkan, mengoreksi, dan bertanya tentang pengelolaan koperasi serta sekaligus untuk dipilih dan memilih menjadi pengurus ataupun pengawas. Dalam masa globalisasi seperti pada saat ini membuat koperasi jarang dilirik oleh para pemilik modal, sebab berapapun seseorang memilik dana, namun tetap saja memiliki satu suara, sehingga koperasi bebas investasi dari pihak yang mempunyai modal besar.

3. Prinsip pembagian sisa hasil usaha dilakukan secara adil sebanding dengan besarnya jasa usaha masingmasing anggota

Anggota adalah pengguna jasa koperasi. Didalam koperasi keuntungan dalam bentuk uang namanya sisa hasil usaha. Sisa hasil usaha adalah selisih antara pendapatan yang diperoleh dengan biaya-biaya yang dikeluarkan dalam pengelolaan usaha. Setiap anggota yang memberikan partisipasi aktif dalam usaha akan mendapatkan bagian keuntungan dari pada anggota yang tidak aktif. Koperasi bukan badan usaha yang berwatak kapitalis sehingga sisa hasil usaha yang dibagikan kepada anggota tidak berdasarkan modal yang dimiliki anggota, tetapi berdasarkan kontribusi jasa usaha yang diberikan anggota kepada koperasi.

4. Prinsip pemberian balas jasa terbatas modal yang dimiliki anggota.

Anggota adalah pemilik koperasi dan sekaligus sebagai pemanfaat jasa. Modal yang disetorkan kepada koperasi pada dasarnya untuk melayani anggota dan dari pelayanan itu koperasi diharapkan mendapatkan nilai lebih dari pendapatan dikurangi biaya. Karena itu balas jasa terhadap modal yang diberikan kepada anggota atau sebaliknya juga terbatas yang tidak semata-mata didasarkan kepada besarnya modal yang diberikan kepada koperasi. Yang dimaksud terbatas adalah pemberian balas jasa atas modal yang ditanamkan disesuaikan dengan kemampuan yang dimiliki koperasi. Jasa yang terbatas artinya bahwa suku bunga atas modal dalam koperasi tidak melebihi suku bunga yang berlaku di pasar. Sehingga jika dikaitkan dengan masa globalisasi, fungsi modal pada koperasi berbeda dengan lembaga keuangan lainnya, sebab koperasi tidak hannya sekedar mencari keuntungan semata (profit motive), akan tetapi dipergunakan untuk pemanfaatan anggota (benefit profit). Prinsip ini adalah prinsip yang paling unik, sebab badan usaha lain tidak memiliki prinsip ini.

5. Prinsip kemandirian koperasi.

Koperasi harus mampu berdiri sendiri dalam hal mengambil keputusan usaha dan organisasi. Kemandirian artinya juga kebebasan yang bertanggung jawab, otonom, swadaya dan keberanian mempertanggung jawabkan segala tindakan sendiri dalam mengelola usaha dan organisasi. Mandiriartinya dapatberdiri sendiri tanpa tergantung pada pihak lainnya. Prinsip ini adalah pendorong bagi koperasi untuk meningkatkan keyakinan akan kekuatan sendiri untuk mencapai tujuan. Pada masa globalisasi seperti pada saat ini prinsip kemandirian sangat diperlukan dalam pengembangan organisasidan usaha. Dengan prinsip ini koperasi dapat bersaing pada masa apapun, karena tidak tergantung dengan pihak lain.

6. Prinsip pendidikan perkoperasian. Keberhasilan koperasi berkaitan erat dengan kualitas yang baik dan berwawasan luas dari semua 
lini, apakah pada level anggota, pengurus, pengawas dan tentunya pengelola beserta karyawanya. Untuk mewujudkan kondisi yang demikian maka pendidikan perkoperasian sangat diperlukan. Dengan sarana pendidikan ini, anggota khususnya dan organ koperasi lainya dipersiapkan dan dibentuk menjadi anggota loyalis, yang memahami, mengerti dan menghayati nilai-nilai dan prinsip-prinsip serta praktek-praktek berkoperasi. Dengan pendidikan ini koperasi akan mampu bersaing di masa globalisasi, karena anggota memahami, mengerti dan menghayati senangnya menjadi anggota koperasi karena mempunyai keunggulan yang tidak dimilki lembaga dan badan usaha lain.

7. Kerjasama antar koperasi.

Bidang usaha koperasi bermacammacam, ada yang usahanya sama ada pula bidang usahanya yang beraneka. Masing-masing usaha tersebut disadari bahwa kemampuan antara satu koperasi dengan kemampuan koperasi lainya tentunya tidak sama. Kerjasama antar koperasi baik pada tingkat kabupaten, propinsi, nasional dan bahkan internasional dimaksudkan untuk saling memanfaatkan kelebihan dan melemahkan kekurangan pada masing-masing koperasi. Sehingga hasil yang akan dicapai akan lebih mudah dan dicapai secara optimal. Apalagi pada masa globalisasi pada saat ini efektitas dan efisiensi sangat dibutuhkan.

Dengan kerjasama antar koperasi diharapkan akan saling menunjang dan mendayagunakan kelebihan antar Koperasi, artinya tercipta sinergitas.

Penerapan nilai dan prinsip-prinsip koperasi merupakan hal yang sangat fundamental dalam suatu Undang-Undang Koperasi. Roh atau pembeda koperasi dengan badan usaha lainya terletak pada roh yang disebut dengan prinsip-prinsip koperasi. Dalam menganalisis penerapan prinsip koperasi pada Undang-Undang No. 25 Tahun 1992 dan Undang-Undang No. 17 Tahun 2012 menurut penulis harus disandarkan pada;

1. Pada hukum dasar negara Indonesia yaitu Undang-Undang Dasar 1945 khususnya pada alenia keempat Pembukaan UUD 1945 “...Kemudian dari pada itu untuk membentuk suatu Pemerintahan Negara Indonesia yang melindungi segenap banagsa Indonesia dan seluruh tumpah darah Indonesia dan untuk memajukan kesejahteraan umum".

2. Pada Pasal 33 ayat (1) UUD 1945: "perekonomian disusun sebagai usaha bersama berdasar atas asas kekeluargaan".

3. Pada Pasal 33 ayat (4) UUD 1945: "Perekonomian nasional diselenggarakan berdasar atas demokrasi ekonomi dengan prinsip kebersamaan, efisiensi berkeadilan, berkelanjutan, berwawasan lingkungan, kemandirian, serta dengan menjaga keseimbangan kemajuan dan kesatuan ekonomi nasional"; dan

4. Pada pengertian koperasi dan prinsipprinsip koperasi yang ditetapkan oleh Internatiaonal Cooperative alliance (ICA); badan atau organisasi dunia yang lain, dan dari para ahli atau tokoh perkoperasian.

Undang-Undang No. 25 Tahun 1992, Pasal 1 menyebutkan koperasi adalah badan usaha yang beranggotakan orang-seorang atau badan hukum koperasi dengan melandaskan kegiatannya berdasarkan prinsip koperasi sekaligus sebagai gerakan ekonomi rakyat yang berdasarkan atas asas kekeluargaan. Sedangkan Undang-Undang No. 17 Tahun 2012 Pasal 1 menyebutkan bahwa yang dimaksud koperasi badan hukum yang didirikan oleh orang perseorangan atau badan hukum koperasi, dengan 
pemisahan kekayaan para anggotanya sebagai modal untuk menjalankan usaha, yang memenuhi aspirasi dan kebutuhan bersama dibidang ekonomi, sosial dan budaya sesuai nilai dan prinsip koperasi.

Dari pengertian koperasi sebagaimana dalam Undang-Undang No. 25 Tahun 1992 bahwa kata "orangseorang" bersifat "individualitas" yang artinya adalah sadar dan memahami bahwa harga dirinya untuk berusaha secara bersama. Berbeda dengan rumusan pada Undang-Undang No. 17 Tahun 2012 dimana kata "Orang perseorangan" bersifat "individualisme" yang artinya mendahulukan kepentingan sendiri dan mengingkari untuk bekerja sama (cooperative). Dengan demikian dapat dianalisis bahwa pengertian koperasi pada Undang-Undang No. 25 Tahun 1992 sesuai dengan alenia keempat pembukaan UUD 1945, Pasal 33 ayat (1) dan 33 ayat (4) serta sesuai pengertian koperasi yang ditetapkan ICA. Sedang pengertian koperasi menurut Undang-Undang No. 17 Tahun 2012 bertentangan dan tidak sesuai dengan pembukaan pada alenia keempat UndangUndang Dasar 1945 dan bertentangan dengan prinsip-prinsip koperasi

Namun mengenai status koperasi sebagai badan hukum penulis sependapat dengan pembuat Undang-Undang No.17 Tahun 2012. Hal ini sebagaimana termuat dalam penjelasan Undang-Undang No. 17 Tahun 2012, bahwa sejarah perjalanan koperasi di Indonesia sudah cukup panjang, dan karenanya usaha perbaikan dari aspek kualitas utamanya dalam menghadapi perubahan tata perekonomian nasional dan global, maka status koperasi sebagai badan hukum, merupakan sesuatu yang perlu diatur dalam Undang-Undang Koperasi. Pengertian koperasi sebagai badan hukum memang mengalami perubahan pada konsep dasar koperasi. Keberlangsungan suatu koperasi sejatinya terletak pada anggota, karena anggota adalah pemilik dan sekaligus pengguna jasa karena koperasi ada karena ada manusia sebagai anggota, sedangkan badan hukum adalah subyek hukum yang adanya karena dianggap sebagai subyek hukum atau badan hukum adalah subyek hukum buatan atau subyek hukum rekaan . Jadi koperasi menurut Undang-Undang No. 17 Tahun 2012 adalah subyek hukum buatan yang didirikan oleh subyek hukum alamiah.

Tentang prinsip-prinsip koperasi pada Undang-Undang No.25 Tahun 1992 yang meliputi;

1. Keanggotaan bersifat sukarela dan terbuka;

2. Pengelolaan dilakukan secara demokratis;

3. Pembagian sisa hasil usaha dilakukan secara adil sebanding dengan besarnya jasa usaha masing-masing anggota;

4. Kemandirian;serta ditambah prinsip pendidikan perkoperasian; dan kerja sama antar koperasi;

Sedangkan prinsip-prinsip koperasi menurut Undang-Undang No. 17 tahun 2012 meliputi;

1. keanggotaan bersifat sukarela dan terbuka;

2. Pengawasan oleh anggota diselenggarakan secara demokratis;

3. Anggota berpartisipasi yang aktif dalam kegiatan ekonomni koperasi;

4. Koperasi merupakan badan usaha swadaya yang otonom dan indipenden

5. Menyelenggarakan pendidikan dan pelatihan bagi Anggota, Pengawas, Pengurus dan Karyawan serta memberi informasi kepada masyarakat tentang jatidiri, kegiatan dan kemanfaatan koperasi;

6. Melayani anggota secara prima dan memperkuat gerakan koperasi, dengan bekerja sama melalui jaringan kegiatan baik tingkat lokal, nasional, regional dan internasional; dan 
7. Bekerjasama untuk pembangunan yang berkelanjutan bagi lingkungan serta masyarakatnya dengan melalui kebijakan yang disepakati oleh anggota.

Pencantuman prinsip-prinsip koperasi baik di dalam UndangUndang No. 25 Tahun 1992 dan Undang-Undang No. 17 Tahun 2012, sebagian besar sudah sesuai dengan Pembukaan Undang-Undang Dasar 1945 khususnya alenia ke empat, Pasal 33 ayat (1), Pasal 33 ayat (4) dan prinsipprinsip koperasi yang di tetapkan oleh International Cooperative Alliance (ICA), bahkan didalam Undang-Undang No. 17 Tahun 2012 selain mencantumkan prinsip-prinsip koperasi sesuai ICA juga ditambah dengan prinsip yang lain, yaitu bekerja sama untuk pembangunan berkelanjutan bagi lingkungan dan masyarakat melalui kebijakan yang disepakati anggota. Disamping itu di dalam Undang-Undang No. 17 Tahun 2012, mencantumkan nilai kegiatan koperasi, antara lain, kekeluargaan, menolong diri sendiri, bertanggung jawab, demokrasi, persamaan, berkeadilan, dan kemandirian, serta mencantumkan nilai yang diyakini anggota koperasi, yaitu, kejujuran, keterbukaan, tanggung jawab, dan kepedulian terhadap orang lain.

\section{Alasan Mahkamah Konstitusi} Membatalkan Undang-Undang Nomor 17 Tahun 2012.

Undang-Undang adalah produk politik yang merupakan kristalisasi kepentingan politik para pembuatnya. Sebagai produk politik isinya mungkin saja mengandung kepentingan ataupun isi dari Undang-Undang tidak sesuai dengan konstitusi sehingga bertentangan dengan konstitusi yang ada. Untuk menguji suatu produk Undang-Undang terhadap UUD atau konstitusi, disediakan mekanisme yaitu yang disebut Judicial Review.

Fungsi dan peran Mahkamah Konstitusi di Indonesia telah dilembagakan dalam Pasal 24C ayat (1) UUD 1945 hasil amandemen, dimana secara garis besar disebutkan bahwa Mahkamah Konstitusi mempunyai empat kewenangan. Adapun kewenangan tersebut adalah, pertama menguji Undang-Undang terhadap UUD 1945, kedua memutus sengketa kewenangan antar lembaga negara, ketiga memutus pembubaran partai politik dan keempat memutus perselisihan hasil pemilu.

Fungsi dan peran Mahkamah Konstitusi yang khusus berkaitan dengan pengujian Undang-Undang terhadap UUD 1945, lebih lanjut diatur dalam Pasal 50, 51, 52, 53, 54, 55, 56, 57, 58, 59 dan Pasal 60 Undang-Undang No.24 Tahun 2003. Pasal 50 Undang-Undang No. 24 Tahun 2003 menentukan bahwa Undang-Undang yang dapat dimohonkan untuk diuji adalah Undang-Undang yang diundangkan setelah perubahan UUD Negara Republik Indonesia 1945. Lebih lanjut Pasal 51 ayat (1) menentukan bahwa pemohon yang mengajukan uji materi Undang-Undang adalah pihak yang menganggap bahwa hak dan atau kewenangan konstitusionalnya dirugikan oleh berlakunya suatu Undang-Undang, dan pihak tersebut adalah, pertama warga negara Indonesia, kedua kesatuan masyarakat hukum adat sepanjang masih hidup dan sesuai dengan perkembangan masyarakat dan prinsip Negara Kesatuan Republik Indonesia, ketiga badan hukum pulik atau privat, dan keempat lembaga negara. Pemohon dalam menyampaikan permohonan uji materi sebagai mana diatur dalam Pasal 50 dan Pasal 51 ayat (1) Undang-Undang No.24 Tahun 2003, wajib menguraikan secara jelas tentang hak dan atau kewenangan konstitusionalnya yang dirugikan dan wajib menguraikan bahwa pembentukan suatu Undang-Undang tidak memenuhi ketentuan berdasarkan UUD negara RI 1945 serta materi baik tentang ayat, pasal dan atau bagian Undang-Undang dianggap bertentangan dengan UUD negara RI 1945. 
Undang-Undang Koperasi Nomor. 25 Tahun 1992 yang sudah berlaku lebih dari 20 tahun, pada saat ini oleh sebagian kalangan dianggap tidak sesuai dengan perkembangan dan kebutuhan hukum, dan karena itu perlu di lakukan pembaharuan Undang-Undang Koperasi. Namun dengan di undangkannnya Undang-Undang Koperasi No.17 tahun 2012 sebagai pengganti Undang-Undang No.25 Tahun 1992, oleh sebagain gerakan dan pegiat koperasi Undang-Undang Koperasi terbaru dianggap merugikan keberadaan koperasi dan bertentangan dengan UUD negara RI 1945, oleh karena itu mereka (sebagian para pegiat dan gerakan koperasi) mengajukan judicial Review.

Terhadapgugatan Yudicial Review, Mahkamah Konstitusi mengeluarkan keputusan Nomor 28/PUU-XI/2013, dimana isi keputusannya adalah bahwa Undang-Undang No.17 Tahun 2012 bertentangan dengan UUD Negara RI 1945, dengan demikian Undang-Undang No.17 Tahun 2012 menurut Pasal 57 ayat (1) dan ayat (2) tidak mempunyai kekuatan hukum dan tidak mempunyai kekuatan hukum yang mengikat.

Alasan atau pertimbangan hukum tentang pembatalan UndangUndang No.17 tahun 2012, bahwa Undang-Undang No.17 Tahun 2012 bertentangan dengan UUD negara RI 1945. Pasal-Pasal yang bertentangan adalah; Pasal 1 ayat (1), Pasal 37 ayat (1) huruf fn bertentangan dengan Pasal 33 ayat (1) UUD negara RI 1945, Pasal 50 ayat (1) huruf a huruf e bertentangan dengan Pasal $28 \mathrm{C}$ dan Pasal 33 ayat (1) UUD negara RI 1945, Pasal 55 ayat (1) bertentangan dengan Pasal 33 ayat (1) dan ayat (4) UUD negara RI 1945, Pasal 56 ayat (1) bertentangan dengan Pasal 28C dan Pasal 33 ayat (1) UUD negara RI 1945 , Pasal 57 ayat (2) bertentangan dengan Pasal 33 ayat (1) UUD negara RI 1945, Pasal 66, Pasal 67, Pasal 78 ayat (2) bertentangan dengan Pasal 28 huruf d ayat (2) dan huruf h ayat (4) dan Pasal 33 ayat (1) UUD negara RI 1945, Pasal 80 bertentangan dengan Pasal 28 d ayat (2) UUD negara RI 1945, Pasal 82 , Pasal 83 dan Pasal 84 bertentangan dengan Pasal 33 ayat (1) dan ayat (4) UUD negara RI 1945

\section{Penutup}

\section{Kesimpulan}

1. Dalam implementasi atau dalam penerapan Undang-Undang harus memperhatikan perkembangan prinsip-prinsip koperasi yang diterapkan secara Internasional, dalam hal ini prinsip-prinsip koperasi yang ditetapkan International Cooperative Alliance dan praktek-praktek bisnis lainya. Penerapan prinsip-prinsip koperasi dalam suatu Undang-Undang Koperasi merupakan hal yang sangat penting dan fundamental, sebab ruh yang membedakan koperasi dengan badan usaha lainya terletak pada prinsip-prinsip koperasi, sehingga apabila pembuatan atau penggantian suatu Undang-Undang Koperasi mengabaikan bahkan meninggalkan prinsip-prinsip koperasi, maka Undang-Undang yang dibuat atau diperbaharui itu sudah meninggalkan ruh dan jatidiri koperasi. Penerapan prinsip-prinsip koperasi pada UndangUndang Koperasi No.25 Tahun 1992 sebagian besar sudah diterapkan, namun pada Undang-Undang Koperasi No.17 Tahun 2012 dalam rangka melakukan pembaharuan hukum koperasi, beberapa Pasal mengabaikan prinsip-prinsip koperasi.

2. Salah satu peran Mahkamah Konstitusi adalah melakukan yudisial review suatu Undang-Undang terhadap Undang-Undang Dasar 1945, sebagaimana diatur dalam Bab IX tentang Kekuasaan Kehakiman khususnya Pasal 24C, bahwa Mahkamah Konstitusi berwenang mengadili pada tingkat pertama dan 
terakhir yang putusannya bersifat final untuk menguji Undang-Undang terhadap Undang-Undang Dasar. Pengaturan Bab IX khususnya pada Pasal 24C Undang Undang Dasar 1945 lebih lanjut diatur didalam Undang-Undang No. 24 Tahun 2003, yaitu Undang-Undang yang mengatur tentang Mahkamah Konstitusi. Usaha pembaharuan hukum koperasi telah dilakukan oleh Pemerintah bersama Dewan Perwakilan Rakyar dengan melakukan penggantian UndangUndang No.25 Tahun 1992 diganti dengan Undang-Undang No.17 Tahun 2012 yang bertujuan meningkatkan aspek kualitas koperasi agar eksistensi koperasi mampu bersaing di dalam era persaingan global. Namun kehadiran Undang-Undang No.17 Tahun 2012 oleh sebagian pegiat koperasi melakukan yudisial review kepada Mahkamah Konstitusi. Berdasarkan kewenangan Mahkamah Konstitusi Undang-Undang No.17 Tahun 2012 dinyatakan bertentangan dengan Undang-Undang Dasar 1945, khususnya bertentangan dengan pembukaan, Pasal 33 ayat (1) dan ayat (4) Undang-Undang Dasar 1945.

\section{Saran}

1. Usaha perbaikan Undang-Undang Koperasi harus dilakukan, agar koperasi keberadaannya terus ada dan mampu sustainabel ditengah- tengah masa globalisasi dan liberalisasi, dan karena itu usaha pembaharuan Undang-Undang Koperasi harus tetap dilakukan namun harus memperhatikan dan menerapkan prinsip-prinsip koperasi agar ruh dan jatidiri koperasi tidak terabaikan. Disamping itu pembaharuan peraturan perundangundangan mengenai Koperasi harus memperhatikan aspek perkembangan dan perubahan hukum ekonomi atau hukum bisnis, agar tujuan yang dicitacitakan yakni meningkatkan aspek kualitas koperasi dapat dicapai tanpa harus meninggalkan prinsipprinsip koperasi sebagai ruh dan jatidiri koperasi.

2. Mengingat peran Mahkamah Konstitusi yang begitu penting, yaitu sebagai penjaga tegakknya konstitusi negara (UUD 1945), maka kegiatan dan usaha mengadakan pemahaman hukum bagi semua komponen bangsa, melalui sosialisasi, seminar dan work shop perlu terus dilakukan, agar pemahaman tentang UndangUndang Dasar 1945 sebagai hukum dasar dapat diketahui oleh semua komponen bangsa, lebih-lebih bagi para pembentuk Undang-Undang.

\section{Daftar Pustaka}

- Buku-Buku:

A.A.G,Peters dan Koesriani, Siswosoebroto, 1990, Hukum dan Perkembangan Sosial, Buku II: Jakarta, Sinar Harapan.

Andjar Pachta W, Myra Rosana Bachtiar, Nadia Maulisa Benemay, 2005, Hukum Koperasi Indonesi, Kencana Prenada Media Grup, Jakarta.

Antonius Cahyadi, E Fernando M, Manulang, 2007, Pengantar Ke Filsafat Hukum: Kencana Prenada Media Grup, Jakarta.

Abdul R.Saliman, 2005, Hukum Bisnis Untuk Perusahaan, Jakarta, Kencana Prenada Media Grup. 
Ace Partadirdja, Ekonomi Etik, 2000, Pidato Pengukuhan Guru Besar Ilmu Sosial, Gadjah Mada Press, Yogyakarta.

Abdulrahman, 1990, Aneka Masalah Hukum Dalam Pembangunan di Indonesia, Alumni, Bandung.

A. Mukthie Fadjar, 2013, Teori-Teori Hukum Kontemporer, Setara Press, Malang.

Bambang Sunggono, 1998, Metode Penelitian Hukum, Raja Grafindo Persada.

Endang Purwaningsih, 2010, Hukum Bisnis, Bogor, Ghalia Indonesia.

Faisal Sanafiah, 1990, Penelitian Kualitatif, Dasar-dasar dan Aplikasi, Penerbit YA3, Malang

Gunawan Sumodiningrat M, 2001, Membangun Perekonomian rakyat, Pustaka Pelajar, Yogyakarta.

Herman Bakir, 2009, Filsafat Hukum, Bandung, Refika Aditama.

Mubyarto, 2003, Amandemen Konstitusi dan Pergulatan Pakar Ekonomi, Aditya Media, Yogyakarta.

----------, 2003, Ekonomi Pancasila, PT.Media Pustaka Indonesia, LP3ES, Jakarta.

----------, 2003, Ekonomi dan Sistem Ekonomi menurut Pancasila dan UUD 1945, Rasda Karya, Bandung

Munir Fuady, 2012, Pengantar Hukum Bisnis, "Menata Bisnis Modern di Era Global", Citra Aditya Bakti, Bandung.

Philip, Nonet dan Philip, Selznick, 2003, Hukum Responsive (Pilihan dimasa Transisi), Ford Foundation HUMA, Jakarta.

Sudikno Mertokusumo, 1986, Mengenal Hukum Suatu Pengantar, Liberty, Yogyakarta. Soetandyo Wignyosoebroto, 2002, "Hukum, Metode dan Dinamika Masalahnya, ELSAMHUMA, Jakarta.

Zaeni Asyhadie, 2012, Hukum Bisnis, Prinsip dan Pelaksanaannya di Indonesia, Raja Grafindo Persada, Jakarta.

- Perundang-undangan:

Undang-Undang Dasar 1945, beserta Amandemen.

Undang-Undang No.25 tahun 1992, Pokok-Pokok Perkoperasian Indonesia.

Undang-Undang No.17 tahun 2012 Tentang Perkoperasian.

Peraturan Pemerintah No.4 Tahun 1994, Persyaratan dan Tata Cara Pengesahan Akta

Pendirian dan Perubahan Anggaran Dasar Koperasi.

Peraturan Pemerintah No.9 Tahun 1994, Pelaksanaan Kegiatan Usaha Simpan Pinjam Oleh Koperasi.

Peraturan menteri Negara Koperasi dan Usaha Kecil dan Menengah Republik Indonesia, No. 20/Per/M.KUKM/XI/2008, Pedoman Penilaian Kesehatan Koperasi simpan Pinjam dan Unit Simpan Pinjam Koperasi.

Peraturan menteri Negara Koperasi dan Usaha Kecil dan Menengah Republik Indonesia,No.14/ Per/M.KUKM/XII/2009, Perubahan Atas Peraturan Menteri Negara Koperasi dan Usha Kecil dan Menengah No. 20/Per/M.KUKM/XI/2008, Pedoman Penilaian Kesehatan Koperasi simpan Pinjam dan Unit Simpan Pinjam Koperasi. 